\title{
SELECTION OF THE BEST RIDE-HAILING BY USING ANALYTIC HIERARCHY PROCESS
}

\author{
Saripudin \\ E-mail: iip@perbanas.id
}

\begin{abstract}
The online-based or ride-hailing service business in Indonesia continues to develop and metamorphose into multifunctional transportation services, this development makes it difficult for customers to determine alternatives to the top two ride hailing services, namely Goride and Grabbike. For this reason, the purpose of this study is to make decisions based on performance, service, security, price, promo and branding criteria to determine the best and make it easier to choose the transportation. The method used is the Analytic Hierarchy Process (AHP) model with the help of Super Decisions software. The data sampling technique was carried out by distributing online questionnaires of 100 respondents to the public using transportation services. The results of this research indicate criteria and alternatives. Shows the Safety Criteria $36.02 \%$, Service Criteria $23.73 \%$, Price Criteria 16.36\%, Promo Criteria $11.29 \%$, Performance Criteria $7.79 \%$, Branding Criteria $4.81 \%$. It seems that security is the most important factor for potential customers because it is related to customer safety, while the two most popular alternatives to Goride and Grabbike are Grabbike. Where GrabBike is superior in terms of cheap prices per kilometer and good branding and everywhere, while Gojek excels in terms of services provided to customers.
\end{abstract}

Keywords : $\quad$ AHP, Super Decisions, Goride, Grabbike, Super Decisions

\section{Introduction}

The increasing number of features on smartphones that are embedded with GPS, coupled with the availability of a digital road map via an API (application programming interface) provides the technology support needed for ordering ride-hailing services. A common feature of ridehailing services is the ability of customers to request drivers and vehicles via a smartphone application that provides the customer's location to the driver via GPS. With the support of GPS technology, digital maps, and routing algorithms, users are provided with real-time waiting time information. (Clewlow, Regina R.Mishra, 2017)

As time went on, the competition between GoJek and Grab became increasingly fierce. Both of them salute each other in developing services and improving their quality. The hope, of course, can get more users than competitors. However, in the end it is the consumer who decides. This is because the Indonesian market is very broad. You can imagine if the total population of Indonesia will reach 270 million by 2020. based on the calculations of the Central Bureau of Statistics, of course it will be a special attraction for business people, especially in the transportation industry. This is because a very large population is clearly accompanied by a high figure for consumption and mobility needs. With a large population of Indonesia, of course it is a special attraction for business people, especially in the transportation industry. This is because a very large population is clearly accompanied by a high figure for consumption and mobility needs. That is why the online transportation ride-hailing industry is flourishing these days. Many players have sprung up, although currently there are only two, namely Go-Jek, a unicorn start-up from Indonesia and Grab, the largest ride-hailing service provider in Southeast Asia. PT GoJek Indonesia and Grab Bike have taken advantage of this opportunity to advance, which can be a 
promising business and provide convenience for users or consumers (Arief, 2019). In terms of usage, Spire Research \& Consulting's research on ride-hailing drivers and customers shows that the brand that has been used in the last six months and three months, Grab outperformed GoJek. This, he said, happened because the promotion of OVO, the e-money offered by Grab, was very attractive during that period. This research also shows the level of customer loyalty of both brands. Research conducted on 280 respondents shows that $50 \%$ of GoJek users are loyal (only using GoJek, not other applications), and there are 66\% loyal Grab users (only using Grab, not other applications). The use of ride hailing is also suspected to have become a daily habit. 58\% (Grabbike) and 64\% (Goride) use a ride-hailing ojek. (Bahar, 2019)

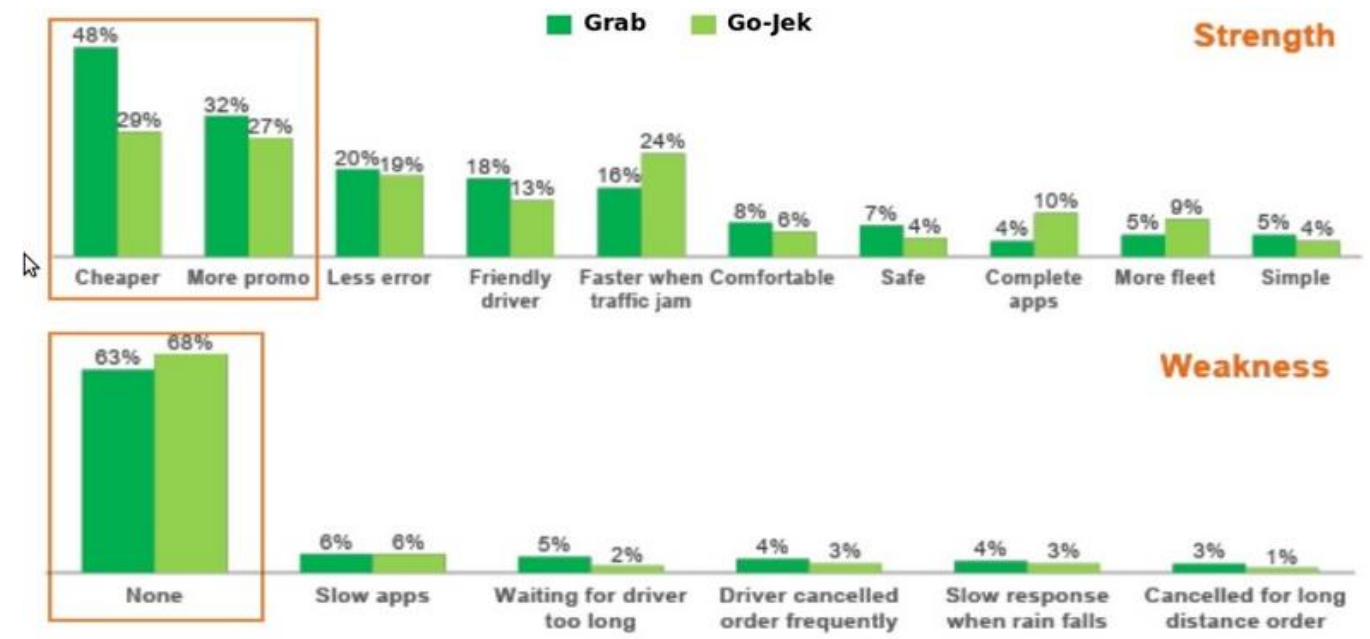

Figure 1. Research results from Spire Research \& Consulting (Hendriani 2019)

This strong competition causes difficulties and confusion for consumers in determining alternatives to the criteria for choosing the two best ride-hailing options. A decision support system (DSS) is a system that can help someone make decisions accurately and in accordance with the desired goals, for that in this study it helps customers determine alternatives to Goride or Grabbika with the criteria of Security, Service, Price, Promo, Performance, The method used is the AHP (Analytical Hierarchy Process) method with the help of software super decisions. .(Saaty, 2005).

\section{Research Method}

Decision making is a choice based on certain criteria on two or more possible alternatives (Syamsi, 2000). States that in their life, human beings frequently face conditions in making decision under some alternative criteria. The AHP method can provide optimum solution in transparent way through: (a) Analysis of the decision in qualitative and quantitative way, (b) Evaluation and representation of the solution in simple way through hierarchical model, (c) Logical argumentation, (d) Test of quality of the decision, and (e) Shorter time reqired (Saaty, 1994).

The AHP method consists of three levels of hierarchy. The first hierarchy level is the goal of the decision making, the second level of hierarchy is how each of the existing criteria contributes to the goal achievement, and the last level of hierarchy is to find out how each of the alternatives contributes to each of the criteria (Exhibit 1). 
International Journal of Economics, Business, and Accounting Research (IJEBAR)

Peer Reviewed - International Journal

Vol-5, Issue-1, 2021 (IJEBAR)

E-ISSN: 2614-1280 P-ISSN 2622-4771

https://jurnal.stie-aas.ac.id/index.php/IJEBAR

(Weinwurm 1961)Taylor (2002: 379) explains that the steps in decision making by using the AHP method are as follows:

1) Establishing Pairwise Comparison Matrix for each decision alternative to each criteria

2) Synthesization

3) Establishing Pairwise Comparison Matrix for each criteria

4) Establishing The Normalized Matrix

5) Establishing The Preference Vector

6) Calculating overall value for each decision alternative

7) Determining the rank of alternatives according to the value acquired in the previous step

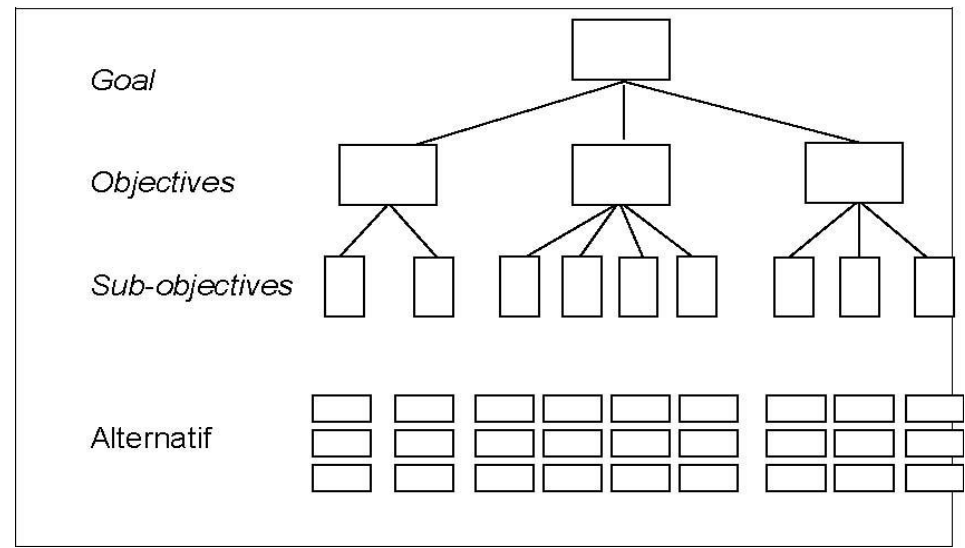

Figure 2 : The Hierarchy level of Decision.

Saaty (1994: 202) states that there are three basic principles in the AHP method, which are as follows:

1) Decomposition

After the problem has been defined, decomposition is necessary to to be done, which is dividing a problem into some smaller parts. The division process will result some levels of a problem. That's why this process of analysis is named hierarchy.

2) Comparative Judgment

This principle assesses the relative importance of two elements in a certain level related to those at higher level. This assessment is the main point of the AHP method because it influences the priority of the elements. This assessment result can be observed better if displayed in the form of Pairwise Comparison Matrix.

3) Synthesis of Priority

From each of Pairwise Comparison Matrix, the eigenvector value can be determined to acquire local priority. Because the Pairwise Comparison Matrix is available in each level, the global priority can be acquired by synthesizing between those local priorities. The procedure of ynthesizing is different according to each hierarchy. To rank the elements according to its relative importance through synthesizing procedure is called priority setting.

According to Saaty (1994:203), this AHP method is appropriate to be used in making decision that involves decision element comparison, which is difficult to be assessed quantitatively. This matter is based on the assumption that human beings' natural reaction when facing a complex decision making, is by grouping the decision elements according to its common characteristics. This grouping process includes rank the decision elements, and then 
International Journal of Economics, Business, and Accounting Research (IJEBAR)

Peer Reviewed - International Journal

Vol-5, Issue-1, 2021 (IJEBAR)

E-ISSN: 2614-1280 P-ISSN 2622-4771

https://jurnal.stie-aas.ac.id/index.php/IJEBAR

comparing between each pair in each group in a form of matrix. Afterward, inconistency ratio and weight for each element will be acquired. Thus, it will provide ease in testing the data consistency.

The ratio-scale form is used as an input in the AHP method, which states one's perception when facing the decision-making situation. The values in the ratio are then organized in a matrix, which is called the pairwise comparison matrix. Due to the limitation of human beings' brain capability, the ratio-scale is limited as well. In the AHP method, the scale range 1-9 is assumed sufficiently representing human beings' perception. The reason why te AHP method limits the ratio-scale 1-9, is acording to the research conducted by a psychologist (Miller, 1956: 256), which shows that human beings cannot simultantly compare more than seven objects, either it increases or decreases two objects. In such condition, human beings will lose their consistency in making the comparison. The Standard Preference Scale used in the AHP method is provided in Table 1 as follows:

\begin{tabular}{|l|c|}
\hline \multicolumn{1}{|c|}{ Preference Level } & $\begin{array}{c}\text { Numerical } \\
\text { Value }\end{array}$ \\
\hline Equally Preferred & 1 \\
\hline Equally to Moderately Preferred & 2 \\
\hline Moderately Preferred & 3 \\
\hline Moderately to Strong Preferred & 4 \\
\hline Strongly Preferred & 5 \\
\hline Strongly to Very Strongly Preferred & 6 \\
\hline Very Strongly Preferred & 7 \\
\hline Very Strongly to Extremely Preferred & 8 \\
\hline Extremely Preferred & 9 \\
\hline
\end{tabular}

Table 1 : The Hierarchy level of Decision.

\section{Types of research}

This research is a descriptive quantitative study, the model used in decision support in this study is the Analytical Hierarchy Process method. While the data collection technique used in this study used an instrument in the form of a questionnaire. A sample that can represent the population is called a representative sample. Representative samples have the same or relatively the same characteristics as the population characteristics. Representative level of the sample taken from a particular population depends on the type of sample used, the size of the sample taken, and the method of collection (Taherdoost 2016). Sample is a set or part of the number and characteristics possessed by the population. Sampling technique is a sampling technique, where the researcher uses purposive sampling, a technique of determining the sample based on chance, that is, anyone who happens to meet the researcher can be used as a sample, if it is considered that the person met is suitable as a data source.(Etikan 2016)

\section{Time and Place of Research}

This research was conducted in Jakarta while the questionnaires were distributed online in the Jakarta, Bekasi, Depok, Bogor areas. The time of this research is November 2019-February 2020. 
International Journal of Economics, Business, and Accounting Research (IJEBAR)

Peer Reviewed - International Journal

Vol-5, Issue-1, 2021 (IJEBAR)

E-ISSN: 2614-1280 P-ISSN 2622-4771

https://jurnal.stie-aas.ac.id/index.php/IJEBAR

\section{Research Target / Subject}

Overall the subjects of this study were ride hailing users, amounting to 100 people spread across Jabotabek. Target / research subject on the criteria that become the main priority for choosing a ride hailing is Security, Service, Price, Promo, Performance, Branding

\section{Procedure}

Super Decisions software implements Analytic Network Process (ANP) for dependency and feedback decision making, a mathematical theory for decision making developed by Dr. Thomas L. Saaty. This theory is an extension of the Analytic Hierarchy Process (AHP) for decision making that involves solving problems into their decision elements, arranging them in a hierarchical structure, making judgments about the relative importance of element pairs and synthesizing the results. Super Decisions aim to make a selection from many alternative options based on predetermined criteria. Types of criteria can be quantitative or qualitative. Quantitative criteria can be designed using a decision maker's preference structure rather than being based on numbers. The structure of a Super Decisions is a model of the best tree (The Best Decision Tree). There is a main goal at the top of the tree that represents the goal of the decision making problem. Decision weight reaching one hundred percent (100\%) is at this point. Directly below the goal is a leaf point that tells the criteria, either qualitative or quantitative. The criteria points divide the weight of the goal by rating. (Saaty, and Vargas, L.G., 2006). Super Decisions create and manage Analytic Network Process (ANP) and Analytic Hierarchy Process (AHP) models, enter user assessment data, obtain results and make Sensitivity Analysis on the results (Saaty, and Vargas, L.G., 2006). Super Decisions are used in determining feedback and dependency decision making. This software applies Analytic Network Process (ANP) and Analytic Hierarchy Process (AHP). (Saaty, 1997).

AHP method of decision making procedure using Super Decisions software.

1. Goal: is the intended target, which is to determine the best Ride Hailing option that can be obtained. Based on existing criteria.

2. Criteria: are the limits set on each alternative choice. Namely: performance criteria, service, security, price and promotions and branding.

3. Alternative: is the choice of options available in this problem. In this case there are 2 top ride hailing rides, namely: Grabbike and Gojek. (Adams and Saaty 2003)

\section{Data, Instruments, and Data Collection Techniques}

The data collection stage is by using a questionnaire, after which the data is processed and entered into the comparison of the criteria for Security, Service, Price, Promo, Performance, Branding in the Super Decisions application, then the consistency is checked, whether it is below 0.1 if the data is consistent below. This study uses a questionnaire which is used as an instrumentation to obtain data in the process of determining the Best Ride Hailing between Grabbike and Goride. Besides that, also interview expert respondents in order to get a software feasibility test

\section{Data analysis technique}

Analysis is an important part of scientific research methodology, because by analyzing the data, it can be given meaning and meaning that is useful in a solution problem. The Analytical Hierarchy Process (AHP) method is a comprehensive decision-making method (Makkasau, 2013). The data analysis used in this research is descriptive analysis and Analytic Hierarchy 
International Journal of Economics, Business, and Accounting Research (IJEBAR)

Peer Reviewed - International Journal

Vol-5, Issue-1, 2021 (IJEBAR)

E-ISSN: 2614-1280 P-ISSN 2622-4771

https://jurnal.stie-aas.ac.id/index.php/IJEBAR

Process (AHP). Descriptive analysis is carried out by presenting a summary of the survey results and identification in tabulated or graphic form. With this analysis will describe the decision making conditions between Grabbike and Goride. While AHP is used as an instrument to determine policy priorities in determining the best Ride hailing.

\section{Results and Discussion}

\subsection{Results}

From several predetermined criteria, a hierarchical structure can be made as a basis for determining decision making using AHP. The hierarchical structure that can be created is as follows:

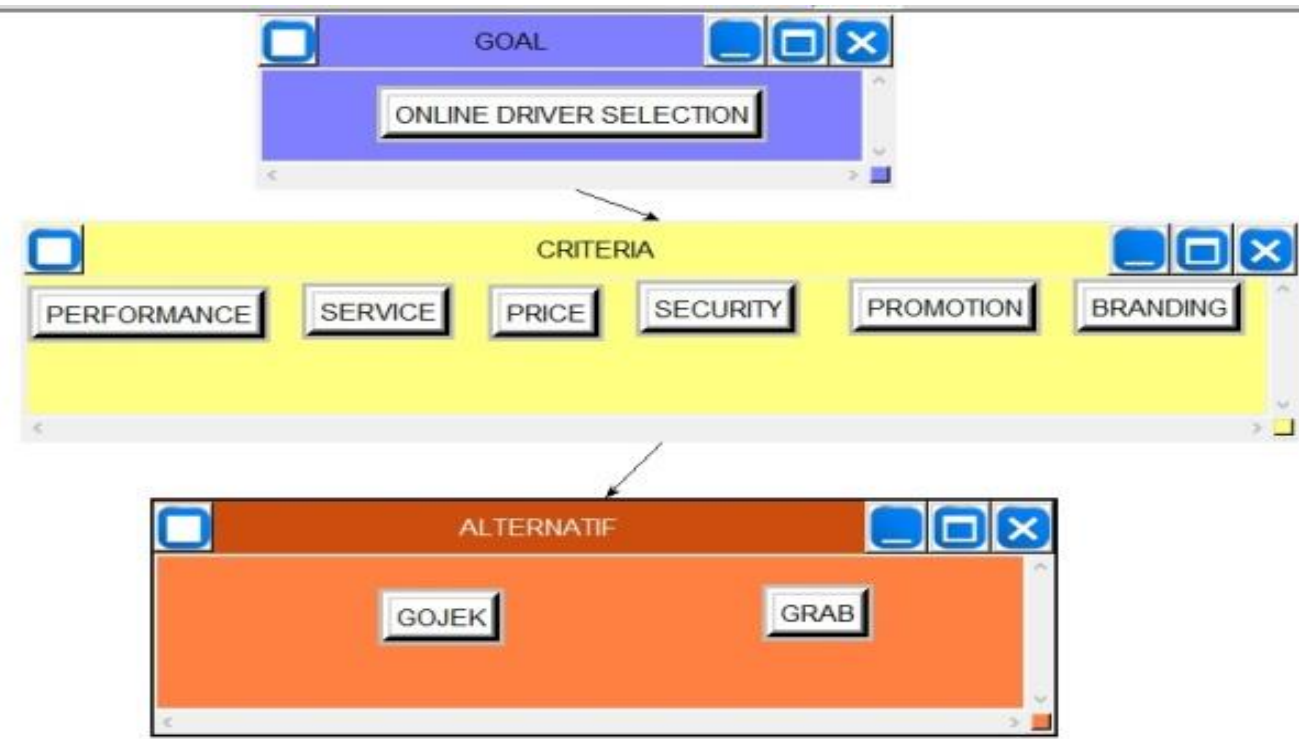

Figure 2. Design relationship between alternatives and criteria

It appears that there are three levels, the first is the goal, namely online transportation drivers, the second is the criteria, namely performance, service, safety, promos and branding, the third is the alternative, namely Grab and Gojek.

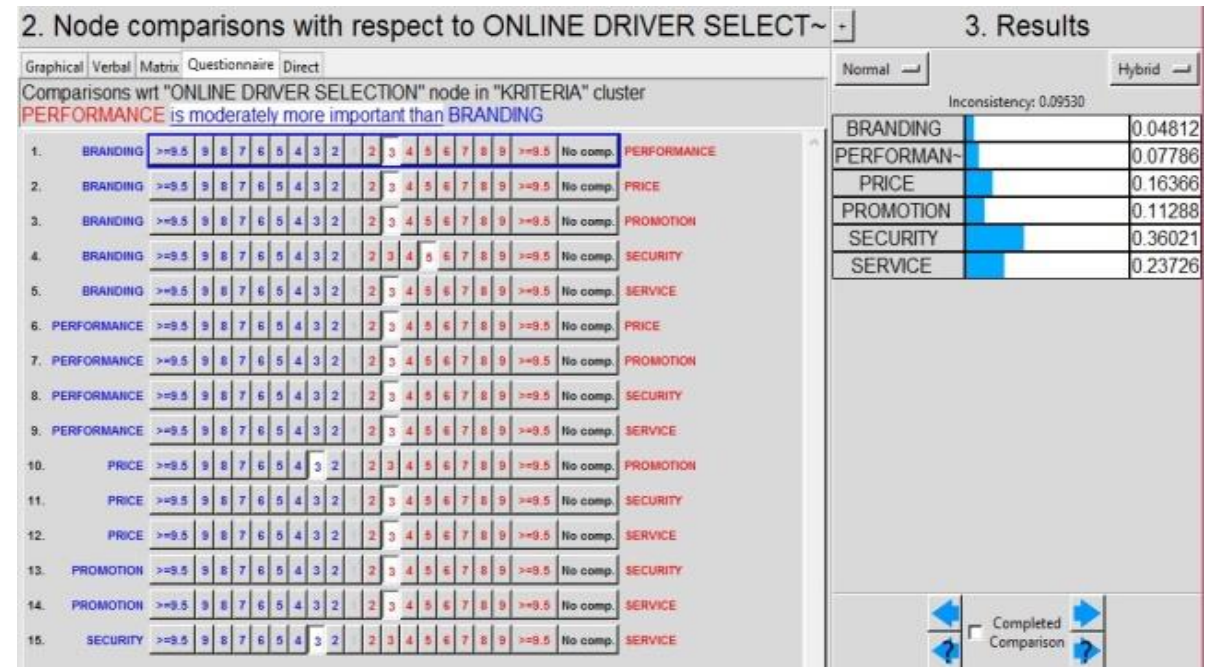

Figure 3. Comparison of criteria 
International Journal of Economics, Business, and Accounting Research (IJEBAR)

Peer Reviewed - International Journal

Vol-5, Issue-1, 2021 (IJEBAR)

E-ISSN: 2614-1280 P-ISSN 2622-4771

https://jurnal.stie-aas.ac.id/index.php/IJEBAR

From the input process the value obtained from the questionnaire shows the comparison between the criteria, where the eigen value for branding is 0.04812 , the eigen value for performance is 0.07786 , the eigen value for price is 0.16366 , the eigen value for promotion is 0.11288 , the eigen value for security is 0.36021 , the eigen value for service is 0.23726 . It can be seen that the inconsistency value of 0.09530 is still below 0.1 based on the consistency ratio (CR).

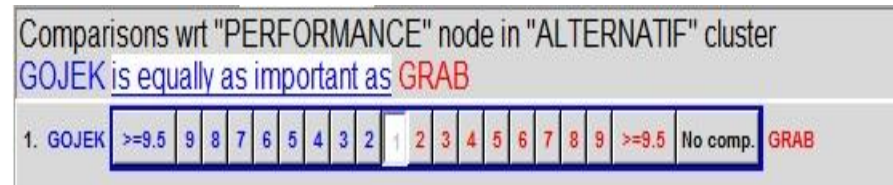

Figure 4.

Comparison of the two alternatives between Grab and Gojek based on Service criteria, where the eigenvalues for Grab 0.25 and Gojek 0.75 and the consistency ratio value is below 0.1

\begin{tabular}{|c|c|c|}
\hline 2. Node comparisons with respect to SERVICE & \multicolumn{2}{|c|}{ 3. Results } \\
\hline Graphical Vetal Matrix Questionaire Direct & Nemal $\triangle$ & How - \\
\hline $\begin{array}{l}\text { Comparisons wrt "SERV CEE" node in "AL TERNATF" cluster } \\
\text { GOJEK is moderately more important than GRAB }\end{array}$ & \multicolumn{2}{|c|}{ Inconsistengy,000000 } \\
\hline 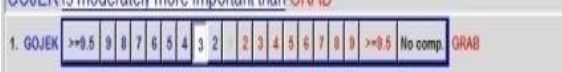 & \begin{tabular}{|l|} 
GONEK \\
GRAB \\
\end{tabular} & $\frac{0.75000}{0.25000}$ \\
\hline
\end{tabular}

Figure 5.

Comparison of the two alternatives between Grab and Gojek based on Service criteria, where the eigenvalues for Grab 0.25 and Gojek 0.75 and the consistency ratio value is below 0.1

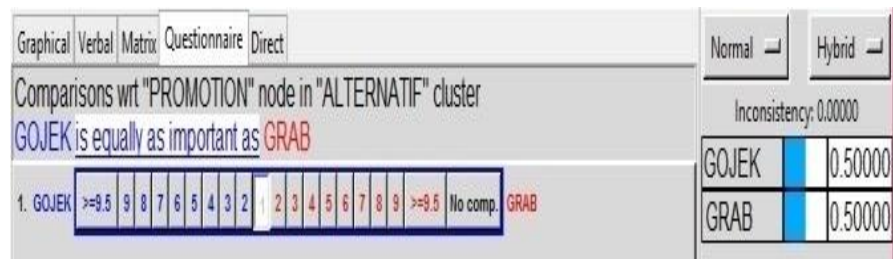

Figure 6.

Comparison of the two alternatives between Grab and Gojek based on Promotion criteria, where the eigenvalues for Grab 0.50 and Gojek 0.50 and the consistency ratio value is below 0.1 .

\begin{tabular}{|c|c|c|}
\hline 2. Node comparisons with respect to PRICE & \multicolumn{2}{|c|}{ 3. Results } \\
\hline Graphical Vebala Matrix Questionarie Direct & Nomal $ـ$ & Howid - - \\
\hline Comparisons wrt "PRICE" node in "ALTERNATIF" cluster & \multicolumn{2}{|c|}{ Inconisitenyy 0.00000} \\
\hline & GOJEK & 0.16667 \\
\hline 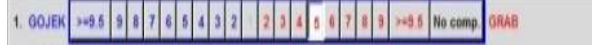 & GRAB & 0.83333 \\
\hline
\end{tabular}

Figure 7.

Comparison of the two alternatives between Grab and Gojek based on Price criteria, where the eigenvalues for Grab 0.16 and Gojek 0.83 and the consistency ratio value is below 0.1 
International Journal of Economics, Business, and Accounting Research (IJEBAR)

Peer Reviewed - International Journal

Vol-5, Issue-1, 2021 (IJEBAR)

E-ISSN: 2614-1280 P-ISSN 2622-4771

https://jurnal.stie-aas.ac.id/index.php/IJEBAR

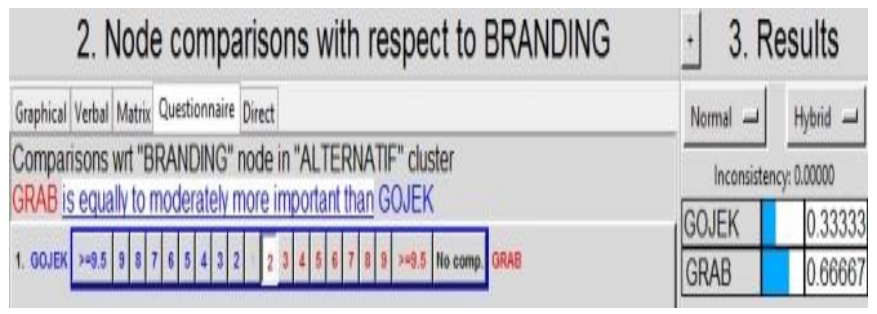

Figure 8.

Comparison of the two alternatives between Grab and Gojek based on Branding criteria, where the eigenvalues for Grab 0.66 and Gojek 0.33 and the consistency ratio value is below 0.1

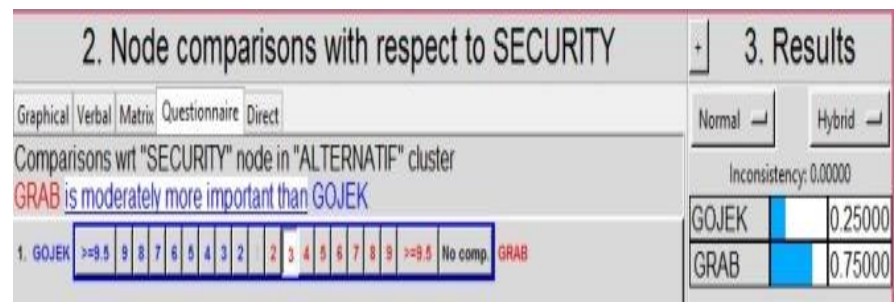

Figure 9.

Comparison of the two alternatives between Grab and Gojek based on safety criteria, where the eigenvalues for grab 0.75 and gojek 0.25 and the consistency ratio value is below 0.1

\subsection{Discussion}

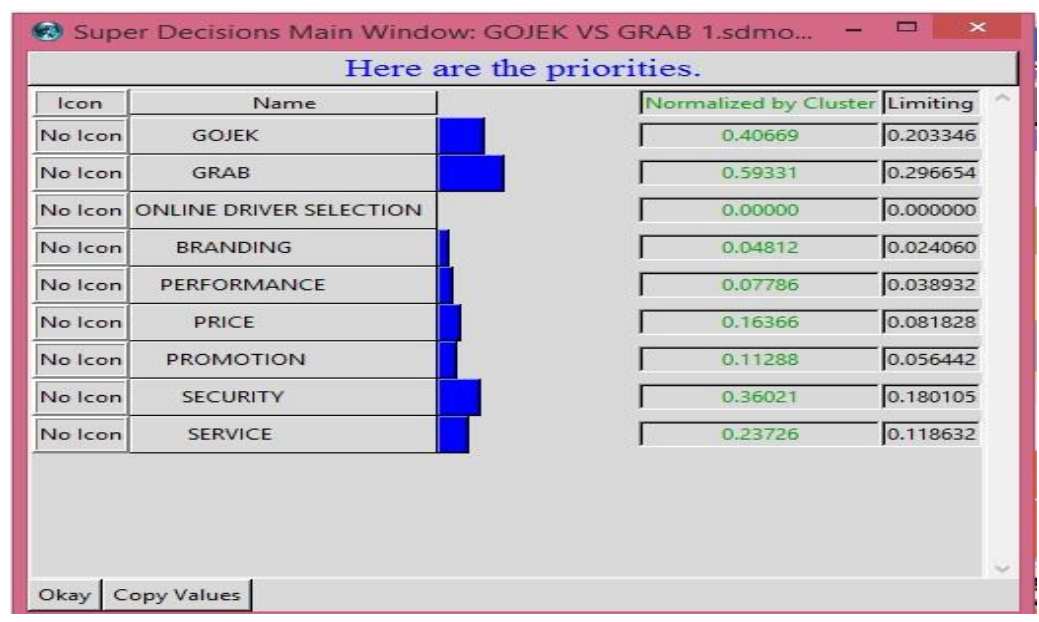

Figure 10.

Priorities for criteria, and alternatives. Shows that the Security Criteria are $36.02 \%$, Service criteria 23.73\%, Price Criteria 16.36\%, Promo Criteria $11.29 \%$, Performance Criteria $7.79 \%$, Branding criteria $4.81 \%$. For an alternative, it looks like Grabbike is worth 0.59 and Gojek is 0.41 . 
International Journal of Economics, Business, and Accounting Research (IJEBAR)

Peer Reviewed - International Journal

Vol-5, Issue-1, 2021 (IJEBAR)

E-ISSN: 2614-1280 P-ISSN 2622-4771

https://jurnal.stie-aas.ac.id/index.php/IJEBAR

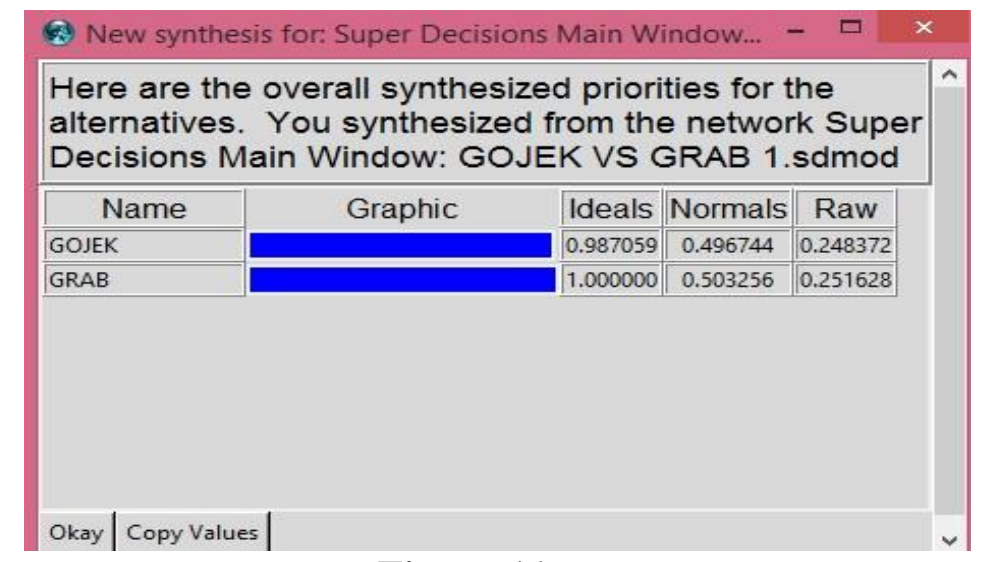

Figure 11.

Overal priorities for the "Ride Hailing" the highest is Grabbike.

\section{Conclusion}

Based on the research that has been done, the following conclusions can be drawn, criteria for online transportation voters are: $36.02 \%$ security criteria, $23.73 \%$ service criteria, $16.36 \%$ price criteria, $11.29 \%$ promo criteria, $7.79 \%$ performance criteria, branding $4.81 \%$. Furthermore, the order of priority for online ojek transportation voters, namely the most important alternative is: GrabBike online transportation received 50.33\%, Gojek online ojek transportation gained $49.67 \%$.

\section{Suggestion}

First, further research can expand the object of research, for example, for business people, school children or others. Second, use the TOPSIS method to strengthen research.

\section{Reference}

Adams, Wj1, and Rw Saaty. 2003. "Super Decisions Software Guide.” Super Decisions.

Arief. 2019. "Pire-Research-Consulting-Persaingan-Transportasi-Online-Makin-Ketat." Https://Wartakota.Tribunnews.Com/2019/02/01/Spire-Research-Consulting-PersainganTransportasi-Online-Makin-Ketat.

Bahar, Jeffrey. 2019. "Persaingan Transportasi Online Makin Ketat."

Clewlow, Regina R.Mishra, Gouri S. 2017. Disruptive Transportation: The Adoption, Utilization, and Impacts of Ride-Hailing in the United States.

Etikan, Ilker. 2016. "Comparison of Convenience Sampling and Purposive Sampling." American Journal of Theoretical and Applied Statistics 5(1):1. doi: 10.11648/j.ajtas.20160501.11.

Hendriani, Lis. 2019. "Ride Hailing Services in Indonesia." Https://Mix.Co.Id/Marcomm/NewsTrend/Ride-Hailing-Services-in-Indonesial, 1.

Kadoić, Nikola, Nina Begičević Ređep, and Blaženka Divjak. 2017. "Decision Making with the Analytic Network Process." Proceedings of the 14th International Symposium on Operational Research, SOR 2017 2017-Septe(September 2006):180-86. doi: 10.1007/0387-33987-6.

$\mathrm{Mu}$, Enrique, and Milagros Pereyra-Rojas. 2018. "AHP Models with Sub-Criteria Using V3." 45-55. doi: 10.1007/978-3-319-68369-0_4.

Saaty, R. W. 1987. "The Analytic Hierarchy Process-What It Is and How It Is Used." 
International Journal of Economics, Business, and Accounting Research (IJEBAR)

Peer Reviewed - International Journal

Vol-5, Issue-1, 2021 (IJEBAR)

E-ISSN: 2614-1280 P-ISSN 2622-4771

https://jurnal.stie-aas.ac.id/index.php/IJEBAR

Mathematical Modelling 9(3-5):161-76. doi: 10.1016/0270-0255(87)90473-8.

Saaty, and Vargas, L.G., 2006. Decision making with the analytic network process, Economic,Political,

Social and Technological Applications with Benefits, Opportunities, Costs and Risks, University

Pittsburgh, Pittsburgh, PA, USA

Saaty, Thomas L. 2008. "Decision Making with the Analytic Hierarchy Process." 1(1).

Taherdoost, Hameed. 2016. "Sampling Methods in Research Methodology; How to Choose a

Sampling Technique for Research Hamed Taherdoost To Cite This Version: HAL Id : Hal-02546796 Sampling Methods in Research Methodology; How to Choose a Sampling Technique For." International Journal of Academic Research in Management (IJARM) 5(2):18-27.

Taylor, Bernard W. 2013. Management Science. 11th ed. edited by Pearson. 